\title{
Pengembangan Model Pembelajaran Motorik Dengan Modifikasi Permainan Tradisional Untuk Meningkatkan Motorik Kasar Anak Sekolah Dasar Kelas Bawah
}

\author{
Muhammad Riyan Hidayatullah ${ }^{1}$, Hasbi $^{2}$ \\ Program Studi Pendidikan Jasmani Kesehatan dan Rekreasi, Fakultas Pendidikan, Universitas \\ Nahdlatul Ulama Nusa Tenggara Barat \\ Email: mriyanhidayatullah@gamil.com ${ }^{1}$, Bi_hasbi@ rocketmail.com²
}

\begin{abstract}
This study aims to produce a motor learning model with modifications of traditional games for lower grade elementary school children. The stages of this research method are educational research and development $(R \& D)$ which adapts development research according to Borg \& Gall (Kurdi \& Sukadiyanto, 2014), namely: (1) potential and problems; (2) information collection; (3) product design (model draft); (4) expert validation and revision; (5) small-scale field trials and revisions; (6) large-scale field trials and revisions; (7) final product manufacture, revision of small-scale trials on 27 lower grade students namely grade II, and grade III at SDN 2 Gerung; (8) large-scale product trial on 40 grade II and third grade students at SD Negeri 1 Gerung; (9) product revision and, (10) benefits and implementation of the development of learning models.The instruments are: (1) interviews; (2) score scales; (3) teacher observations; (4) observation of the effectiveness of the model, and (5) student questionnaires. Data analysis techniques are descriptive qualitative and quantitative analysis. Results This research is in the form of a motor learning model with modifications a traditional game for lower grade elementary school children which contains five games, namely: (1) Gobak Sodor, (2) Jemprak/Engklek, (3) Grave Jumping, (4) Cat and Mouse, (5) Zig-Zag Sack Race, compiled in the form of a manual. From the results of data analysis on the assessment of material experts and student questionnaires, it can be concluded that the motor learning model with modified traditional games for lower grade elementary school children has a positive and effective response. This is evidenced by the percentage of each qualitative data requested is above $75 \%$ on a large scale, so that it can be used in physical education learning in elementary schools.
\end{abstract}

Keywords: Motor Learning Model, Modification of Traditional Games.

\section{Abstrak}

Penelitian ini bertujuan untuk menghasilkan model pembelajaran motorik dengan modifikasi permainan tradsional untuk anak sekolah dasar kelas bawah. Adapun tahapan metode penelitian ini merupakan penelitian pengembangan (education research and development $(R \& D)$ yang mengadaptasi penelitian pengembangan menurut Borg \& Gall (Kurdi \& Sukadiyanto, 2014) yaitu: (1) potensi dan masalah; (2) pengumpulan informasi; (3) desain produk (draf model); (4) validasi ahli dan revisi; (5) uji coba lapangan skala kecil dan revisi; (6) uji coba lapangan skala besar dan revisi; (7) pembuatan produk final, revisi uji coba skala kecil pada 27 siswa kelas bawah yaitu kelas II, dan kelas III di SDN 2 Gerung; (8) uji coba produk skala besar pada 40 siswa kelas II dan kelas III SD Negeri 1 Gerung; (9) revisi produk dan, (10) kemanfaatan dan implementasi pengembangan model pembelajaran. Instrumen yaitu: (1) wawancara; (2) skala nilai; (3) observasi guru; (4) observasi keefektifan model, dan (5) kuesioner siswa. Teknik analisis data yaitu analisis deskriptif kualitatif dan kuantitatif. Hasil penelitian ini berupa model pembelajaran mtorik dengan modifikasi permainan tradisional untuk anak sekolah dasar kelas bawah yang berisi lima permainan yaitu: (1) Gobak Sodor, (2) Jemprak/Engklek, (3) Lompat Kubur, (4) Kucing dan Tikus, (5) Balap Karung Pola Zig-Zag, yang disusun dalam bentuk buku panduan. Dari hasil analisis data penilain para ahli materi dan kuesioner siswa, dapat di simpulkan bahwa model pembelajaran motorik dengan modifikasi permainan tradisional untuk anak sekolah dasar kelas bawah di respon positif dan efektif. Hal ini dibuktikan dengan jumlah persentase pada setiap data kualitatif yang diminta di atas $75 \%$ pada skala besar, sehigga dapat digunakan dalam pembelajaran penjaskes di sekolah dasar.

Kata Kunci: Model Pembelajaran Motorik, Modifikasi Permainan Tradisional.

\section{PENDAHULUAN}

Pembelajaran motorik merupakan salah satu bagian dari pembelajaran pendidikan jasmani di sekolah, yang dibebankan tanggung jawab mencapai tujuan pembelajaran agar anak memiliki keterampilan gerak yang memadai, baik dari aspek psikmotorik, kognitif, maupun aspek afektif nya. Keterampilan gerak merupakan kemampuan yang seharusnya dimiliki siswa sebagai bekal dalam mengembangkan gerak siswa di masa selanjutnya. Dengan mengembangkan motorik anak dapat mengaktualisasikan bakat, potensi dan minat siswa yang di sesuiakan dengan kompetensi inti maupun kompetensi dasar (KI/KD).

Pembelajaran motorik di sekolah dasar saat ini menjadi perhatian banyak kalangan, hal ini disebabkan pada masa usia sekolah dasar merupakan masa intelektual atau masa yang menentukan 
pertumbuhan dan perkembangan selanjutnya. Oleh karena itu, penerimaan berbagai pengalaman keterampilan gerak yang intensif melalui proses pembelajaran motorik dalam pendidikan jasmani di sekolah dasar menjadi penting. Melalui pembelajaran motorik di sekolah dasar akan berpengaruh terhadap beberapa aspek kehidupan para siswa seperti: (1) melalui pembelajaran motorik anak mendapatkan hiburan dan memperoleh kesenangan, (2) melalui pembelajaran motorik anak dapat beranjak dari kondisi lemah menuju kondisi independen, (3) melalui pembelajaran motorik anak dapat menyesuaikan diri dengan lingkungan, (4) melalui pembelajaran motorik akan menunjang keterampilan anak dalam berbagai hal, dan (5) melalui pembelajaran motorik akan mendorong anak bersikap mandiri, sehingga dapat menyelesaikan segala persoalan yang dihadapinya (Decaprio, 2013, p.24).

Anak merupakan masa yang ideal untuk mempelajari keterampilan motorik tertentu. Masa ideal belajar keterampilan secara umum berkisar antara usia 3 s/d 13 tahun (Husdarta \& Kusmaedi, 2010,p : 103). Sesuai dengan karakteristik dan perkembangan motorik anak sekolah dasar kelas bawah sangat tepat untuk diajarkan keterampilan motorik. Anak sekolah dasar yang sejak dini (kelas rendah) menerima berbagai jenis keterampilan gerak, akan lebih mudah dalam menerima keterampilan gerak serupa di masa kehidupan berikutnya. Anak juga menjadi lebih efisien dalam menampilkan keterampilan gerak tersebut. Singer (Sukadiyanto, 2012, p.1) menyatakan pendapat senada bahwa pengalaman dan praktek intensif dalam berbagai keterampilan motoric akan menghasilkan kemudahan dalam penguasaan keterampilan. Oleh karena itu, individu yang pada masa kecilnya memiliki berbagai pengalaman pola gerak dasar dan berbagai aktivitas, akan lebih mudah melakukan berbagai keterampilan motorik.

Dengan demikian keterampilan gerak dasar (motorik kasar dan motorik halus) dalam bentuk gerak lokomotor, non-lokomotor dan manipulasi yang diberikan pada anak sekolah dasar menjadi fondasi dalam pembelajaran keterampilan motorik yang baru atau menuju pada kualitas keterampilan jasmani pada tingkat selanjutnya.

Berdasarkan hasil studi pendahuluan terhadap aktivitas guru dan siswa dalam pelajaran penjaskes guru SD Negeri 1 Mesanggok dan SD Negeri 3 Gerung Utara, ditemukan beberapa masalah yang dihadapi baik oleh guru maupun siswa di kedua sekolah tersebut dalam hal pembeajaran motrik yaitu (1) kurangnya pemahaman dan kretaivitas guru dalam menyusun stategi model pembelajaran motorik yang variatif ,menarik dan menyenagkan, sehingga berpengaruh terhadap proses pembelajaran yang masih bersifat konvensional, (2) kurangnya sarana prasarana yang mendukung dan memadai dalam proses pembbelajaran motorik dalam pendidikan jasmani; (3) kurangnya jumlah jam pelajaran pendidikan jasmani dalam memberikan materi pembelajaan motorik yang memerlukan waktu lama dalam proses belajarnya sehingga gerak siswa tidak maksimal.

Dari proses analisis terhadap hasil studi pendahuluan dan wawancara terhadap guru Pendidikan jasmani di SD Negeri 1 Mesanggok dan SD Negeri 3 Gerung Utara, untuk memperoleh gambaran yang jelas mengenai suatu model pembelajaran motorik yang menarik dan menyenangkan, oleh karena itu peneliti mencoba melakukan penelitian dengan judul "Pengembangan Model Pembelajaran Motorik Dengan Menggunakan Modifikasi Permainan Tradisional Untuk Anak Sekolah Dasar Kelas Bawah'.

Permasalahan dalam penelitian ini adalah Pengembangan model pembelajaran motorik dengan modifikasi permainan tradisional untuk meningkatkan motorik kasar anak sekolah dasar kelas bawah.

Tujuan dalam penelitian ini adalah untuk menghasilkan model pembelajaran motorik dengan menggunakan modifikasi permainan tradisional untuk anak sekolah dasar kelas bawah yang menaik, efektif dan menyenangkan yang dapat digunakan guru pendidikan jasmani.

\section{METODE}

\section{Jenis Penelitian}

Penelitian ini merupakan penelitian pengembangan (education research and development $(R \& D)$. Sukmadinata (2011, p.164) menyatakan bahwa penelitian pengembangan adalah suatu proses atau langkah-langkah untuk mengembangkan suatu produk baru atau menyempurnakan produk yang telah ada, yang dapat dipertanggungjawabkan.

\section{Prosedur Pengembangan}

Langkah-langkah tersebut diadaptasi menjadi (7) rancangan prosedur penelitian pengembangan yaitu (1) pengembangan informasi di lapangan, (2) analisis informasi, (3) mengembangkan produk awal (Draf Model), (4) validasi ahli dan revisi, (5) uji coba lapangan skala kecil dan revisi, (6) uji coba lapangan skala besar dan revisi dan (7) pembuatan produk final.

\section{Uji Coba Produk dan Data Penelitian}

Uji cobaproduk/draft model dilakukan sebanyak 2 kali yaitu uji coba skala kecil dan uji coba skala besar. Uji coba produk skala kecil dilakukan 
terhadap siswa kelas III SDN 2 Gerung, yang berjumlah 24 anak, sementara uji coba skala besar dilakukan terhadap siswa kelas II dan III SDN 1 Gerung, yang berjumlah 40 siswa. Jenis data yang diperoleh dalam penelitian dan pengembangan ini yaitu data kualitatif dan data kuantitatif.

Data kualitatif berasal dari (a) hasil wawancara dengan guru pendidikan jasmani SD, (b) data kekurangan model permainan dari ahli materi dan guru yang melakukan uji coba permainan, dan (c) data masukan ahli materi dan guru pelaku uji coba terhadap model permainan. Data kuantitatif diperoleh dari (penilain ahli materi terhadap permainan), (d) penilain ahli materi terhadap guru pelaku uji coba.

Pengumpulan data dilakukan dengan wawancara, observasi, dan skala nilai dengan menyusun kategori. Kategori yang dimaksud dalam skala penilitian ini adalah kategori berskala dua, yaitu sesuai dan tidak sesuai. Cara penggunaan skala penilaian yaitu, bilamana muncul gejala atau unsurunsur seperti yang terdapat dalam klarifikasi data, para pakar dan guru memberikan tanda cek (v) pada kolom kategori yang sesuai (Nawali \& Handari (2006, pp.79-81) apabila gejala atau unsur-unsur seperti yang terdapat dalam klarifikasi data ditanyakan sesuai maka nilainya satu (1), apabila ditanyakan tidak sesuai maka nilainya nol (0).

\section{Teknik Analisis Data}

Data kuantitatif untuk menghitung kuantitas data dengan analisis, terlebih dahulu menentukan persentase dari hasil observasi dengan rumus menurut Sudijono, (2011, pp.40-41) sebagai berikut

Keterangan:

$$
\mathrm{P}=\frac{\mathrm{F}}{\mathrm{N}} \times 100 \%
$$

$\mathrm{P} \quad$ : Persentase skor aktifitas yang diperoleh

F : skor aktifitas yang diperoleh berdasarkan deskriptor

$\mathrm{N}$ : skor maksimal.

Tabel 1. Pedoman konversi nilai skala 5 (Zaenal Arifin, 2014: 236)

\begin{tabular}{|l|c|l|}
\hline Rentan Skor Nilai & Kategori & Keterangan \\
\hline $80 \%$. s.d.100\% & $\mathrm{A}$ & $\begin{array}{l}\text { Sangat } \\
\text { baik/efektif }\end{array}$ \\
\hline $70 \%$ s.d.79\% & $\mathrm{B}$ & Baik/efekif \\
\hline $60 \%$ s.d.69\% & $\mathrm{C}$ & Cukup baik/efektif \\
\hline $45 \%$ s.d.59\% & $\mathrm{D}$ & $\begin{array}{l}\text { Kurang } \\
\text { baik/efektif }\end{array}$ \\
\hline$<44 \% \mathrm{E}$ & $\mathrm{E}$ & Tidak baik/efektif \\
\hline
\end{tabular}

Data kualitatif yang terdiri dari: (1) data hasil wawancara dengan guru SD saat studi pendahuluan, (2) data kekurangan dan masukan terhadap model permainan baik sebelum uji coba maupun setelah uji coba, diperoleh langsung melalui analisis deskripsi masing-masing masukan, dan kekurangan terhadap model permainan ini.

\section{Indikator Keberhasilan}

Data Kuantitatif indikator keberhasilan yang dijadikan alat ukur dalam penelitian dan pengembangan model pembelajaran ini adalah, apabila persentase hasil data yang bersifat kuantitatif berupa: (1) data skala nilai hasil penelitian para ahli materi terhadap draft model permainan sebelum pelaksanan uji coba di lapangan, (2) data hasil observasi para ahli materi terhadap model permainan, (3) data hasil observasi para ahli materi terhadap permainan, (4) hasil observasi para ahli materi terhadap guru pelaku uji coba, adalah sama atau di atas $70 \%$, maka dapat dikatakan bahwa model pembelajaran motorik dengan modifikasi pendekatan permainan tradisional dapat mengembangkan atau memperbaiki aspek motorik kasar pada peserta didik. Sedangkan indikator keberhasilan data kuantitatif untuk mengukur kinerja anak saat melakukan model permainan (aktifitas siswa) adalah sama atau lebih dari nilai 70 untuk masing-masing aspek yang dinilai dalam tiap permainan.

Data kualitatif, pengembangan model pembelajaran motorik dengan modifikasi pendekatan permainan tradisional ini dikatakan berhasil dengan melihat langsung deskripsi dari: (1) data hasil wawancara dengan guru SD saat studi pendahuluan, (2) data kekurangan dan masukan terhadap model permainan baik sebelum uji coba maupun setelah uji coba.

\section{HASIL DAN PEMBAHASAN Pelaksanaan Permainan Tradisional Gobak Sodor}

Tujuan Pembelajaran Dalam Permainan Gobak Sodor. 1) Mengembangkan kesadaran tubuh, kesadaran ruang dan arah (ranah motor), 2) Mengembangkan berbagai variasi dalam gerak (indikator ranah kognitif), 3) Mengembangkan kemampuan gerak lokomotor, non-lokomotor, dan manifulatif (indikator motorik), 4) Meningkatkan kemampuan fisik kelinciahan ( indikator ranah motorik), 5) Melatih kerjasama dan bersosial dalam bermain gobak sodor (indikator ranah afektif). Peralatan: lapangan sekolah, kapur/cat, peluit, alat tulis, bol plastik warna warni, keranjang plastik, dan $\mathrm{jam} /$ stopwach.

Peraturan dalam permainan gobak sodor yang di modifikasi adalah guru membuat lapangan Gobak Sodor dengan mengukur panjang dan lebar lapangan $17 \mathrm{~m}$ x $9 \mathrm{~m}$. 
Membagi luas lapangan menjadi 14 bagian (lapangan Gobak Sodor disesuaikan dengan jumlah peserta didik). Dalam satu petak/kotak ukurannya 2 meter jarak dengan kotak yang lain. Bentuk aktivitas dapat dilihat pada gambar 1 berikut.
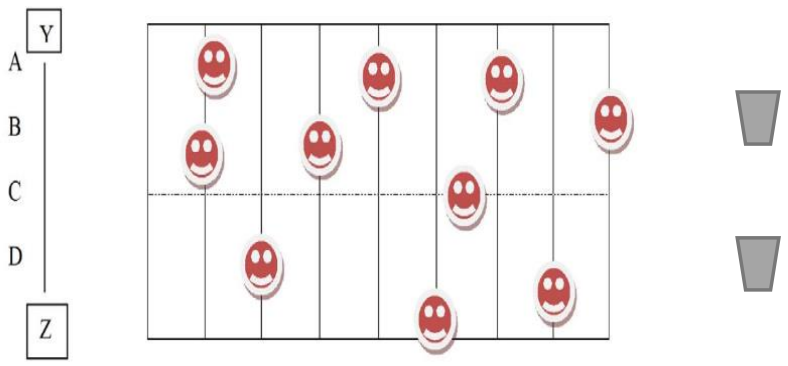

Gambar 1. Bentuk Modifikasi Lapangan Gobak Sodor.

Permainan terdiri dari 2 regu masingmasing kelompok terdiri dari 12 orang dan yang 3 orang menjadi tim cadangan di masing-masing kelompok. Sebelum permainan di mulai diadakan undian, yang kalah sebagai tim penjaga an yang menang sebagai tim penyerang. Regu penjaga menempati garisnya masing-masing dengan kedua atau salah satu kaki berada di atas garis, sedangkan regu penyerang siap untuk masuk menerobos hadangan dengan membawa bola plastik warna warni untuk di masukkan ke dalam keranjang, setelah melewati tim penjaga. Permainan dimulai setelah wasit membunyikan peluit. Penyerang berusaha untuk menghindari tim hadang sehingga tidak tersentuh oleh tim penjaga, apabila tim penyerang tersentuh sebanyak sepeluh kali (10) maka tim penyerang dikatakan mati dan tim penyerang berganti menjadi tim penjaga. setelah tim penyerang sampai di tahap akhir maka tim penyerang berusaha memasukkan bola ke dalam keranjang sebanyak mungkin dan berbalik arah untuk melakukan permainan seperti permainan biasa. Lihat gambar 2 di bawah ini.

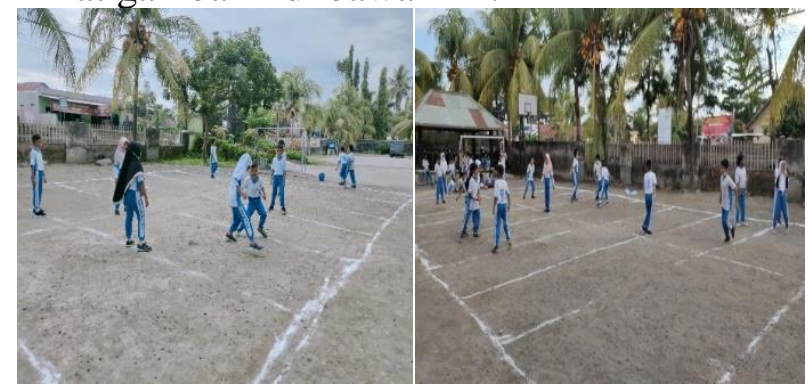

Gambar 2. Aktivitas Peserta didik saat melakukan permainan Gobak Sodor.
(Sumber: dokumentasi pribadi)

Setiap kelompok berusaha untuk melakukan permainan dengan sempurna (bentuk kompetisi yang bersifat rekreatif). Peserta didik harus berusaha menerobos di setiap garis sodor dengan membawa bola plastik warna warni dan berusaha untuk menghindari sentuhan dari tim penjaga garis, setelah tim penyerang sudah mencapai finish dan mengumpulkan bola kedalam keranjang sebanyak-banyaknya, maka tim penyerang berusaha untuk masuk ke petak sodor berbalik arah dan berusaha untuk menyelesaikan permainan dengan melewati tim penjaga sodor sampai selesai. Terlihat dari gambar peserta didik semakin bersemangat dalam melakukan aktivitas permainan sodor.

\section{Pelaksanaan Permainan Tradisional Engklek/Jemprak}

Tujuan Pembelajaran

Mengembangkan kesadaran tubuh, kesadaran ruang dan arah ranah motor). 2) Memahami berbagai gerakan lompat (indikator kognitif). 3) Mengembangkan kemampuan gerak lokomotor, non-lokomtor, dan gerak manifulatif. 4) Melaksanakan tugas kegiatan sendiri dan tugas kelompok sampai selesai (indikator ranah afektif). Peralatan: lapangan, kapur, bola plastik, dan keranjang plastik.

Pengaturan cara bermain dan bentuk aktivitas seperti gambar 3 di bawah ini.

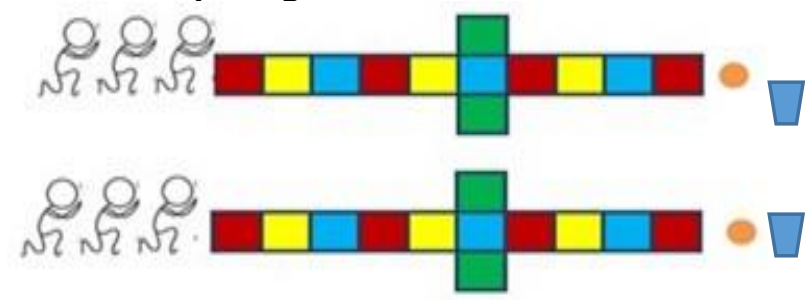

Gambar 3. Bentuk Modifikasi Permiainan Engklek

Peserta didik dibagi menjadi 2 kelompok dan setiap kelompok berbaris ke belakang. Guru menjelaskan aturan dalam permainan jemprak/engklek dan membeikan modelan setelah peserta didik sudah jelas dan permainan siap untuk di mulai. Siswa di bariskan berbanjar ke belakang sebelum melakukan lompatan terhadap area lapangan permainan. Siswa melakukan jingkatan dengan posisi kaki terangkat dan melalui setiap petak/kotak setelah sampai ke petak akhir maka posisi kaki kanan siswa tetap dalam keaadaan di angkat dengan 
berusaha mengambil bola dan memasukkan bola ke dalam keranjang, apabila bola berhasil di masukkan maka mendapat 1 poin. Jika siswa tidak memasukkan bla ke dalam keranjang maka siswa tersebut tidak mendapatkan poin. perhatikan gambar 4 di bawah ini.

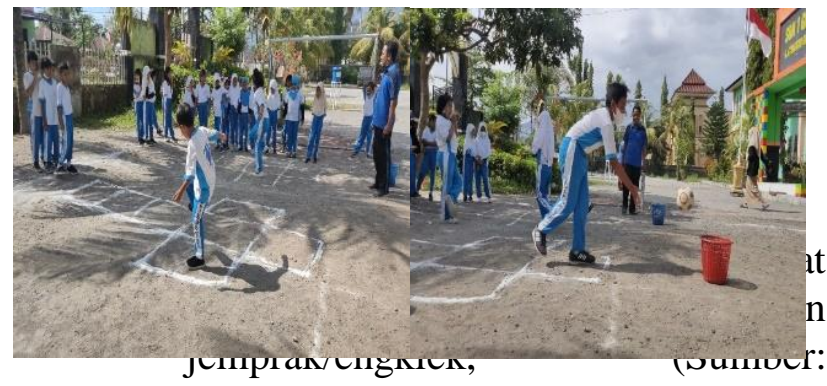

dokumentasi pribadi).

\section{Pelaksanaan Permainan Tradisional Lompat Kubur}

Tujuan Pembejaran 1) Mengembangkan kesadaran tubuh, kesadaran ruang dan arah (ranah motor). 2) Meningkatkan gerak lari, kecepatan, lmpat, jengket, kelincahan dan koordinasi (indikator ranah motorik). 3) Mengembangkan kemampuan gerak lokomotor, non-lokomotor, dan geak dasar manifulatif (indikator motorik). 4) Dapat bekerjasama dalam melaksanakan tugas kelompok (indikator ranah afektif). 5) Memamahami konsentrasi (indikator kognitif). Peralatan: botol plastik, peluit, stopwach, dan bendera. Pengaturan dan bentuk aktivitas lihat gambar 5 di bawah ini.

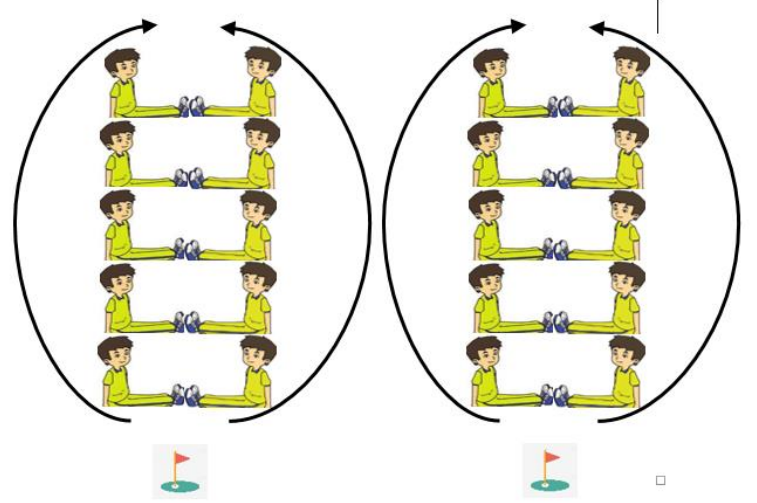

Gambar 5. Bentuk Modifikasi Permaianan Lompat Kubur

Siswa di bariskan dengan posisi duduk berhadapan dengan teman nya dalam posisi duduk kaki di luruskan. Posisi kaki siswa saling bertemu membentuk sebuah kotak-kotak kecil, siswa di tentukan nama/pasangan duduk, dalam permainan ini siswa di suruh untuk menyebut nama kelompok dengan huruf mulai dari $\mathrm{A}$ sampai seterus nya sesuai dengan jumlah pasangan/kelompok duduk. Setelah permainan jelas maka guru memberikan aba-aba siap, lalu guru memanggil kelompok untuk memulai permainan, setelah dipanggil guru membunyikan peluit siswa segera bergerak untuk memulai permainan, kelompok yang pertama di panggil guru maka kelompok tersebut yang pertama kali mengambil bendera yang sudah di sediakan guru di depan akhir permainan, setelah bendera dapat di ambil oleh kelompok tersebut maka kelompok tersebut melakukan lompatan dengan berusaha melewati setiap kaki teman nya sampai selesai dan duduk di tempat semula. Kelompok pertama menyerahkan bendera pada kelompok berikut aturan nya sepeti cabang olahraga lari estafet bergantian memberikan tongkat estafet. Setelah kelompok A menyelesaikan lompatan sampai di tempat duduk semula, maka kelompok A menyerahkan bendera ke kelompok B aturan nya sama sepeti semula, dan kelompok terakhir yang akan menanjapkan bendera ke dalam botol plastik yang sudah di sediakan.

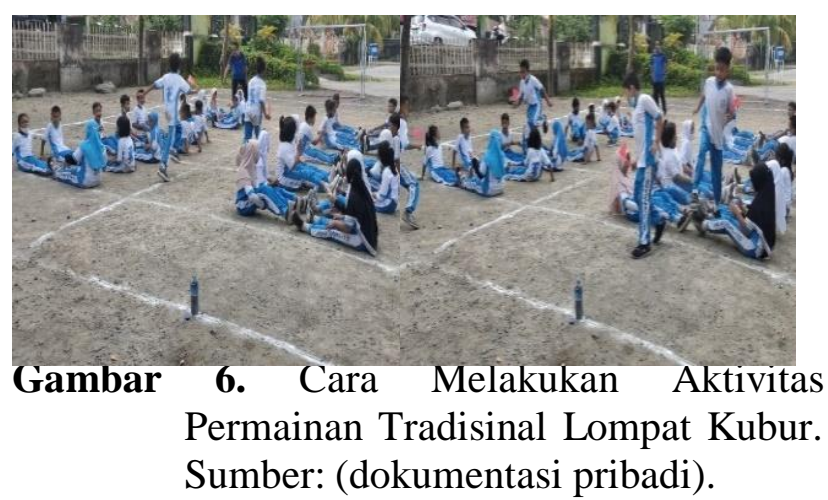

\section{Pelaksanaan Permainan Tradisional Kucing Dan Tikus}

Tujuan

pembelajaran

Mengembangkan kesadaran tubuh, kesadaran ruang dan arah (ranah motor. 2) Memahami konsentrasi (indikator ranah kognitif). 3) Mengembangkan kemampuan gerak lokomotor (indikator motorik). 4) Meningkatkan kemampuan motorik kasar, kelincahan, dan kecepatan (indikator ranah motorik). 5) Dapat bekerjasama dalam melaksanakan tugas kelompok (indikator ranah afektif). Dalam permainan Kucing-Tikus tidak menggunakan peralatan hanya menggunakan halaman atau tempat yang kosong. Peraturan dan bentuk 
aktivitas adalah guru membuat sebuah lingkaran dengan cara mengukur seperti berputarnya jarum jam. Zona lingkaran/batas disesuaikan ukurannya dengan banyaknya jumlah peserta didik. Jika jumlah peserta didik banyak maka ukuran zona diperbesar. Pengaturan dan bentuk aktivitas dapat dilihat pada gambar 7 .

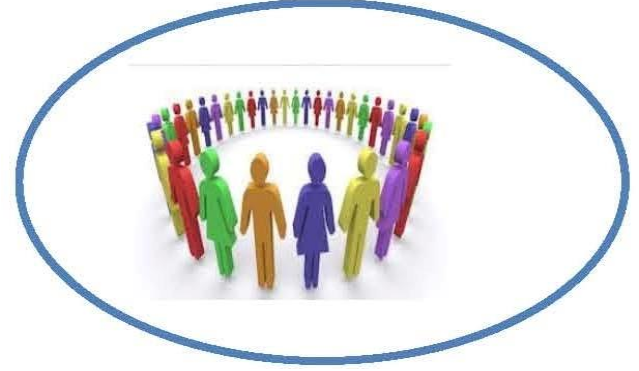

Gambar 7. Lapangan Permainan Kucing Dan Tikus.

Sebelum permainan di mulai, guru menentukan nomor urut masing-masing siswa, guru menunjukkan dua siswa yang mengejar dan yang dikejar, misal nya yang di tunjuk nomor 5 (sebagai kucing) dan 7 (sebagai tikus) maka nomor 5 harus mengejar nomor 7 begitu seterus nya. Jikalau nomor 7 sudah tersentuh/di tangkap oleh nomor 5 maka hukuman untuk nomor 7 adalah menggedng nomor 5 dan guru melanjutkan permainan dengan aturan yang sama, lihat gambar 8 di bawah ini.

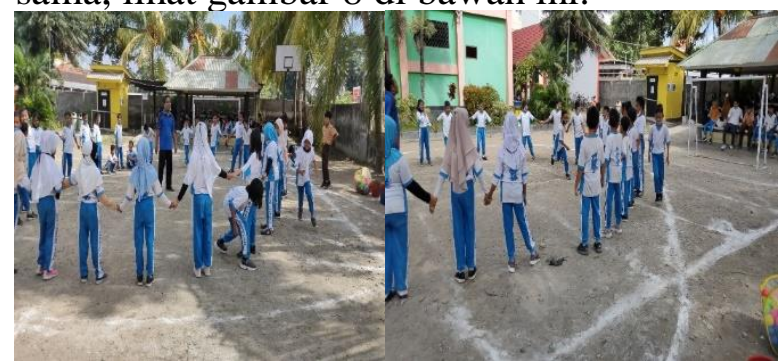

Gambar 8. Aktivitas Peserta Didik Saat Melakukan Permainan Kucing Dan Tikus.

\section{Pelaksanaan Permainan Tradisional Balap Karung Pla Zig-Zag}

Tujuan

pembelajaran

Mengembangkan kesadaran tubuh, kesadaran ruang dan arah (ranah motorik). 2) Memahami konsentrasi (indikator ranah kognitif). 3) Mengembangkan kemampuan gerak lokomotor (indikator motorik). 4) Meningkatkan kemampuan motorik kasar, kelincahan, dan kecepatan (indikator ranah motorik). 5) Dapat bekerjasama dalam melaksanakan tugas individu (indikator ranah afektif). Dalam permainan Balap Karung menggunakan peralatan yang sederhana halaman/lintasan bermain dan karung.

Peraturan dan bentuk aktivitas adalah guru menyiapkan 2 buah lintasan balap karung yang berbentuk kotak, berukuran panjang 40x40 $\mathrm{cm}$ dengan pola zig-zag. Perhatikan gambar 9 berikut ini.

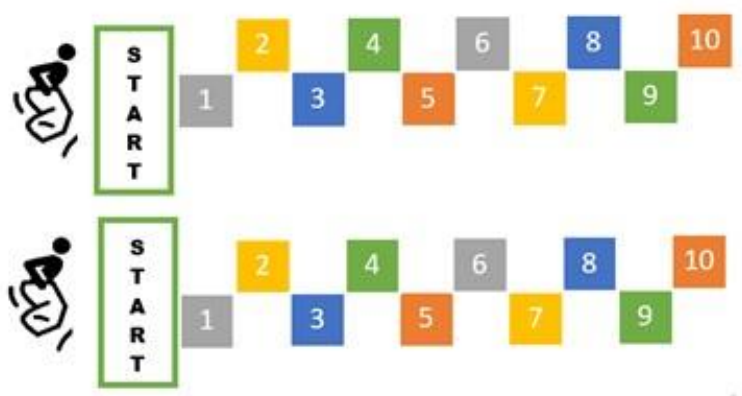

Gambar 9. Lintasan Balap Karung Pola Zigzag.

Guru memanggil satu persatu peserta didik untk melakukan permainan balap karung dengan pla zig-zag, berdiri pada garist start dan mengenakan karung yang telah disediakan. Setelah peserta didik sudah berada dalam psisi siap, maka guru akan memberikan aba-aba dan meniup peluit tanda dimulain nya permainan. Guru menentukan nomor mana yang akan di injak/diloncati oleh peserta didik dengan aturan yang sudah ditentukan. Peserta didik akan berusaha melakukan loncatan sampai dengan seterus nya dengan melakukan konstetrasi mendengarkan nomor mana yang akan di loncati. Setelah peserta didik sampai di petak/kotak terakhir dengan nomor yang sudah dii sediakana dalam bentuk zig-zag, maka peserta didik segera berbalik arah kembali ke garis start. Seteiap peserta didik tidak boleh keluar dari lintasan permainan. Apabila ada peserta didik yang keluar darii lintasan, atau melakukan injakan/loncatan engan nomr yang tidak ditentukan guru, maka hukkuman bagi peserta didik yang melanggar aturan harus mengulang permainan dari kotak sebelum nya, dan kelompok yang menyelesaikan permainan terlebih dahulu denggan baik adalah pemenang nya. Perhatikan gambar 10 dibawah ini. 


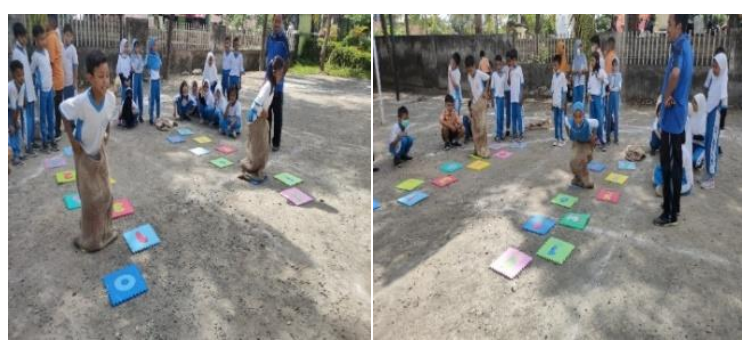

Gambar 10. Aktivitas siswa saat melakukan permainan Balap Karung Pola ZigZag. Sumber: (dokumentasi pribadi).

\section{Data Masukan Dari Ahli Materi}

Draf awal model permainan tradisional diajukan ke ahli materi dan dari proses tersebut peneliti menerima masukan-masukan terhadap permainan.

Tabel 2. Masukan Ahli Materi Terhadap Draft Awal Model Pembelajaran Motorik Modifikasi Permainan Tradisional

\begin{tabular}{|c|c|}
\hline Ahli Materi & $\begin{array}{l}\text { Masukan Teradap Model Pembelajaran } \\
\text { Permainan Modifikasi } \\
\text { Tradisional }\end{array}$ \\
\hline $\begin{array}{ll}\text { Guru } & \text { SDN } \\
(\text { Shrmn }) & \\
\end{array}$ & Alokasi waktu permainan tidak cukup \\
\hline Pakar 1 (Yudha) & $\begin{array}{l}>\quad \text { Lapangan permainan gobak sodor } \\
\text { ditambahkan menjadi dua lapangan } \\
\text { agar semua siswa aktif bergerak } \\
\text { dalam pembelajaran } \\
>\quad \text { Lintasan lapangan kurang jelas }\end{array}$ \\
\hline $\begin{array}{l}\text { Pakar } \\
\text { (Nengsih) }\end{array}$ & $\begin{array}{l}>\quad \text { Dalam permainan gobak sodor } \\
\text { lintasan di perjelas } \\
>\quad \text { Siswa semua harus aktif }\end{array}$ \\
\hline
\end{tabular}

Tabel 3. Masukan Ahli Materi Draft Awal Model Pembejaran Motrik Modifikasi Permainan Tradisional

\begin{tabular}{|c|c|}
\hline Ahli Materi & $\begin{array}{l}\text { Masukan Teradap Model Pembelajaran } \\
\text { Permainan Modifikasi Permainan } \\
\text { Tradisional Jemprak/Engklek }\end{array}$ \\
\hline $\begin{array}{l}\text { Guru SDN } \\
\text { (Shrmn) }\end{array}$ & - \\
\hline $\begin{array}{ll}\text { Pakar } & 1 \\
\text { (Yudha) } & \end{array}$ & $\begin{array}{l}\text { Jarak keranjang di } \\
\text { kemampuan anak SD kelas bawah }\end{array}$ \\
\hline $\begin{array}{lr}\text { Pakar } & 2 \\
\text { (Nengsih) } & \end{array}$ & $>$ Semua siswa menggunakan sepatu \\
\hline
\end{tabular}

Tabel 4. Masukan Ahli Materi Draft Awal Model Pembejaran Motorik Modifikasi Permainan Tradisional

\begin{tabular}{l|l}
\hline Ahli Materi & $\begin{array}{l}\text { Masukan Model } \\
\text { Pembelajaran Permainan Modifikasi } \\
\text { Permainan Tradisional Lompat Kubur }\end{array}$
\end{tabular}

\begin{tabular}{l|ll}
\hline $\begin{array}{l}\text { Guru } \\
\text { (Shrmn) }\end{array}$ & \multicolumn{3}{l}{} \\
\hline Pakar 1 (Yudha) & $>$ & $\begin{array}{l}\text { Jarak bendera di sesuaikan } \\
\text { karakteristik anak SD kelas Bawah }\end{array}$ \\
\hline Pakar 2 (Nengsih) & $\begin{array}{l}\text { Semua siswa menggunakan } \\
\text { sepatu }\end{array}$
\end{tabular}

Tabel 5. Masukan Ahli Materi Draft Awal Model Pembejaran Motorik Modifikasi Permainan Tradisional

\begin{tabular}{l|ccc}
\hline Ahli Materi & $\begin{array}{l}\text { Masukan Teradap Model Pembelajaran Permainan } \\
\text { Modifikasi Permainan Tradisional kucing dan tikus }\end{array}$ \\
\hline $\begin{array}{l}\text { Guru SDN } \\
\text { Shrmn) }\end{array}$ & - & \\
\hline Pakar 1 (Yudha) & $>$ & Lingkaran permainan di perjelas & \\
\hline $\begin{array}{l}\text { Pakar } \\
\text { (Nengsih) }\end{array}$ & Pengkondisian siswa harus di \\
perhatikan
\end{tabular}

Tabel 6. Masukan Ahli Materi Draft Awal Model Pembelajaran Motrik Modifikasi Permainan Tradisional

\begin{tabular}{l|c}
\hline Ahli Materi & $\begin{array}{l}\text { Masukan Teradap Model Pembelajaran } \\
\text { Permainan Modifikasi Permainan Tradisional } \\
\text { Balap Karung Pola Zig-Zag }\end{array}$ \\
\hline Guru SDN (Shrmn) & - \\
\hline Pakar 1 (Yudha) & - \\
\hline Pakar 2 (Nengsih) & $\begin{array}{l}\text { Jarak di setiap nomor tidak terlalu jauh sehingga } \\
\text { siswa tidak kesulitan ketika melakukan loncatan }\end{array}$
\end{tabular}

\section{Analisis Data Masukan Dari Ahli Materi}

Analisis data permainan Gobak Sodor terdapat beberapa masukan dari ahli materi terhadap model permainan. Masukan pertama dari ahli yaitu bahwa permainan gobak sodor lapangan di tambahkan menjadi dua lapangan sehigga semua siswa ikut aktif bergerak. Dari masukan tersebut, peneliti selanjutnya melakukan revisi terhadap draft model dengan membuat dua lapangan gobak sodor. Oleh karena itu, lapangan permainan dibuatkan menjadi dua lapangan agar semua siswa dapat bergerak aktif dalam pembelajaran.

Masukan dari ahli kedua yaitu lintasan atau lapangan gobak sodor lebih di perjelas, dan masukan dari Guru SD alokasi waktu di tambahkan.

Analisis data permainan Engklek/Jemprak terdapat beberapa masukan dari ahli materi yaitu jarak keranjang di sesuaikan dengan kemampuan anak SD kelas bawah, masukan ahli kedua yaitu semua siswa menggunakan sepatu. Peneliti selanjutnya melakukan revisi terhadap draft model 
pembelajaran dengan menyesuaikan keadaan lingkungan sekolah.

Analisis data permainan Lompat Kubur terdapat beberapa masukan dari ahli materi pertama yaitu, Jarak bendera di sesuaikan karakteristik anak SD kelas Bawah, sedangkan ahli materi kedua yaitu dalam permainan lompat kubur semua siswa harus menggunakan sepatu untuk menjaga kemungkinan cidera/kena serta posisi duduk siswa di kondisikan.oleh karena itu peneliti selanjutnya melakukan revisis terhadap draf model permainan agar dalam permainan lompat kubur semua siswa memakai sepatu, serta mengkondisikan jarak duduk siswa dengan siswa lain nya.

Analisis data permainan Kucing dan Tikus terdapat beberapa masukan dari ahli materi pertama yaitu, garis lingkaran atau zona pembatas harus di perjelas dan dari ahli materi kedua yaitu pengkondisian siswa.

Analisis data permainan Balap Karung Dengan Pola Zig-Zag, ada beberapa masukan dari ahli materi kedua yaitu, jarak di setiap nomor tidak terlalu jauh sehingga siswa tidak kesulitan ketika melakukan loncatan. Selanjutnya peneliti melakukan revisi sesuai dengan masukan dari ahli materi kedua.

\section{Analisis Data Validasi Ahli}

Dari hasil penelitian skala nilai yang diberikan pakar/ahli materi terhadap revisi draf awal model sebelum diujicobakan dilapangan, para ahli materi: (1) Dr. L.Moh.Yudha Isnaini, M.Pd (bidang ahli pembelajaran penjas), (2) Wahyu Hanananingsih, M.Pd (Bidang ahli permainan), dan 2 Guru penjas sekolah dasar sependapat bahwa model pembelajaran permainan dengan modifikasi permainan tradisional yang terdii dari 5 permainan, yaitu: (1) gobak sodor, (2) engklek/jemprak, (3) lompat kubur, (4) kucing dan tikus, dan (5) balap karung dengan pola zig-zag, yang di modifikasi dinilai telah sesuai, dengan adanya item-item atau hasil observasi penilain skala nilai dinyatakan layak untuk diiujicoba di lapangan.

\section{Analisis Data Uji Coba Skala Kecil}

Uji coba skala keil dilakukan di SD Negeri 2 Gerung Utara dengan sampel siswa kelas bawah yaitu kelas, II, dan kelas III (Tiga) yang terdiri dari 27 siswa.

Analisis data observasi ujicoba skala kecil
Dari penilain ahli materi terdapat instrumen observasi pada ujicoba skala kecil, para ahli materi sependapat bawha model pembelajaran permainan yang terdiri dari 5 macam modifikasi permainan, yaitu: : (1) gobak sodor, (2) engklek/jemprak, (3) lompat kubbur, (4) kucing dan tikus, dan (5) balap karung dengan pola zig-zag, yang dikembangkan termasuk dalam kategori baik dan efektif.

Walaupun model sudah memenuhi itemitem obsevasi, namun terdapat beberapa masukan dari ara ahli materi yaitu: (1) permainan gobak sodor ditambahkan lapangannya dan pengkondisian siswa, ( 2) engklek/jemprak ukuran keranjang di sesuaikan dengan karakteristik peserta didik. Menyikapi masukan dari para ahli materi terdapat model yang dimodifikasi, peneliti seanjutnya melakukan perbaikan untuk penyempurnaan produk lebih lanjut sebelum melakukan ujicoba skala besar.

Analisis Data Kuesioner Guru Pelaku Uji Coba Dilapangan

Dari hasil data observasi untuk guru pelaku uji coba dilapangan menunjukkan bahwa dalam menerapkan model-model permainan yang sudah di rancang pelaku ujicoba terlihat efektif dalam pemakaian terhadap peserta didik.

\section{Analisis Data Kueisoner Siswa}

Dari hasil data kueisoner untuk siswa menunjukkan bahwa rrespon dari peserta didik yang menjadi sampel ujicoba skala kecil, secara umum memberikan respon yang positif terhadap model pembelajaran motorik dengan modifikasi permainan tradisional terdapat $(3,7 \%)$ yang mengalami kesulitan saat mengikuti pembelajaran dengan model yang dimodifikasi, hal ini dikarenakan kondisi tingkat konstenrasi siswa yang tidak sama serta karakteristik siswa sekolah dasar masih berada pada usia tumbuh kembang.

\section{Analisis Uji Coba Skala Besar}

Uji coba skala besar dilakukan di SD Negeri 1 Gerung dengan sampel siswa kelas bawah yaitu kelas II, dan kelas III (Tiga) yang terdiri dari 40 siswa.

Analisis Data Uji Coba Skala Besar

Dari penilain ahli materi terdapat instrumen observasi pada ujicoba skala kecil, paa ahli materi sependapat bahwa model pembelajaran permainan yang terdiri dari 5 
macam mmodifikasi permainan, yaitu: : (1) gobak sodor, (2) engklek/jemprak, (3) lompat kubur, (4) kucing dan tikus, dan (5) balap karung dengan pola zig-zag, yang dikembangkan termasuk dalam kategori baik dan efektif.

Berdasarkan hasil observasi dari ahli materi terdapat pelaksanaan ujicoba skala besar model pembelajaran modifikasi permainan tradisional, ahli materi menganggap bahwa model yang dimodifikasi sudah baik daan efektif. Sehingga tidak ada lagi masukan atau revisi.

\section{Analisis Data Kuesioner Guru Pelaku Uji} Coba Dilapangan

Dari hasil data observasi untuk guru pelaku ujicoba di lapangan menunjukkan bawah dalam menerapan model permainan yang sudah dirancang ujioba terlihat efektif dalam pemakaian terhadap produk pembelajaran permainan tradisional untuk anak sekolah dasaar kelas bawah.

\section{Analisis Data Kuesioner Siswa}

Dari hasil data kuesioner siswa menunjukkan bawah respon dari peserta didik yang menjadi sampel ujicoba skala besar. Secara umum memberikan respon positiif terhadap model pembelajaran dengan modifikasi permainan tradisional terdapat $(1,0 \%)$ yang mengalami kesulitan dalam mengikuti proses pembelajaran permainan tradisional yang di modifikasi, hal ini dikarena kondisi siswa yang kurang fokus dan tingkat kebugaran siswa yang tidak sama serta karakteristik siswa sekolah dasar masih berada pada usia tumbuh kembang.

\section{Revisi Produk Uji Coba Skala Kecil}

Berdasarkan analisis data observasi dan masukan dari ahli materi pada ujicoba skala kecil, maka dilakukan revisi terhadap prduk yang dikembangkan. Revisis produk yang dilakukan hanya pada beberapa bagian saja, kaena para pakar/ahli menggap bahwa model pembelajaran modifikasi permainan tradisional yang dikembangkan sudah baik dan efektif, namun masih perlu dilakukan revisi terhadap produk. Revisi produk setelah diujicoba skala kecil yang dilakukan yaitu: (a) pada model permainan sodor diilakukan revisis terhadap penambahan lapangan dan garis lapangan permainan, (b) pada permainan engklek/jemprak pengkondisian siswa dan jarak tempat melempar bola di sesuaikan dengan karaktersistik peserta didik, (c) pada model permainan lompat kubur semua siswa di sarankan menggunakan sepatu.

\section{Validasi Ahli Materi}

Ujicoba di lapangan terhadap model permainan dapat dilaksanakan setelah mendapat validasi dari para pakar dan guu SD oleh karena itu, di ajukan revisi draf awal model permainan untuk mendapatkan valdasi. Sebelum melakukan validasi, ahli materi menilai revisi draf awal model permainan dengan menggunakan instrumen skala penilaian sebagai bahan panduan dalam menilai permainan terdapat 15 item klariifikasi dalam skala nilai untuk pembelajaran motrik, ahli dalam pembelajaran pendidikan jasmani dan guru penjaskes sekolah dasar (SD).

Dari hasil penilain para pakar/ahli materi terdafat draf awal model pembelajaran motorik dalam permainan tradisional, di paparkan pada tabel 6, 7 dan 8 berikut ini.

Tabel 7. Penilain skala nilai pakar 1 (bidang ahli pembelajaran)

\begin{tabular}{|c|c|c|c|c|c|c|c|c|c|c|c|c|c|c|c|c|}
\hline \multirow{2}{*}{\begin{tabular}{l|} 
Model \\
permainan
\end{tabular}} & \multicolumn{14}{|c|}{ Item klarifikasi } & \multirow{2}{*}{\begin{tabular}{|l|}
$\begin{array}{l}\text { Total } \\
\text { nilai }\end{array}$ \\
15
\end{tabular}} & \multirow{2}{*}{$\begin{array}{l}\text { Persentase } \\
(\%) \\
100\end{array}$} \\
\hline & 1 & 2 & \begin{tabular}{|l|}
3 \\
\end{tabular} & \begin{tabular}{l|l}
45 \\
\end{tabular} & \begin{tabular}{l|l}
5 &
\end{tabular} & 67 & 18 & 9 & 10 & 11 & 12 & 13 & 14 & & & \\
\hline 1 & 1 & 1 & 1 & \begin{tabular}{l|l}
1 & 1
\end{tabular} & 1 & 1 & 1 & 1 & 1 & 1 & 1 & 1 & 1 & 1 & 15 & 100 \\
\hline 2 & 1 & 1 & 1 & 1 & 1 & 1 & 1 & 1 & 1 & 1 & 1 & 1 & 1 & 1 & 15 & 100 \\
\hline 3 & 1 & 1 & 1 & 1 & 1 & 11 & 1 & 1 & 1 & 1 & 1 & 1 & 1 & 1 & 15 & 100 \\
\hline 4 & 1 & 1 & 1 & 1 & 1 & 1 & 1 & 1 & 1 & 1 & 1 & 1 & 1 & 1 & 15 & 100 \\
\hline 5 & 1 & & 1 & 1 & 11 & 11 & 1 & 1 & 1 & 1 & 1 & 1 & 1 & 1 & 15 & 100 \\
\hline
\end{tabular}

Keterngan: Total nilai 15, dengan persentase $100 \%$ dapat dikatakan bahwa model pembelajarann ini layaka untuk di ujicoba. Apabila total nilai $<15$, dan kurang dari $75 \%$, maka dapat dikatakan bahwa model pembelajaran ini belum layak untuk di ujicoba.

Berdasarkan penilaian pakar/ahli motorik Dr. L.Moh.Yudha Isnaini, M.Pd terdapat draft awal mddel pembelajaran motorik dengan pendekatan bermain menggunakan permainan tradisional, terlihat bahwa total nilai dari masingmasing model telah memenuhi persyaratan kelayakan untuk di ujicoba di lapangan.

Tabel 8. Penilain skala nilai pakar 2 (bidang ahli permainan)

\begin{tabular}{|l|l|l|l|l|l|l|l|l|l|l|l|l|l|l|l|l|l|}
\hline \multirow{2}{*}{$\begin{array}{l}\text { Model } \\
\text { permainan }\end{array}$} & \multicolumn{1010}{|l|}{ Item klarifikasi } \\
\cline { 2 - 16 } & 1 & 2 & 3 & 4 & 5 & 6 & 7 & 8 & 9 & 10 & 11 & 12 & 13 & 14 & 15 & 15 & 100 \\
\hline 1 & 1 & 1 & 1 & 1 & 1 & 1 & 1 & 1 & 1 & 1 & 1 & 1 & 1 & 1 & 1 & 15 & 100 \\
\hline 2 & 1 & 1 & 1 & 1 & 1 & 1 & 1 & 1 & 1 & 1 & 1 & 1 & 1 & 1 & 1 & 15 & 100 \\
\hline 3 & 1 & 1 & 1 & 1 & 1 & 1 & 1 & 1 & 1 & 1 & 1 & 1 & 1 & 1 & 1 & 15 & 100 \\
\hline 4 & 1 & 1 & 1 & 1 & 1 & 1 & 1 & 1 & 1 & 1 & 1 & 1 & 1 & 1 & 1 & 15 & 100 \\
\hline 5 & 1 & 1 & 1 & 1 & 1 & 1 & 1 & 1 & 1 & 1 & 1 & 1 & 1 & 1 & 1 & 15 & 100 \\
\hline
\end{tabular}


Keterngan: Total nilai 15, dengan persentase $100 \%$ apat dikatakan bahwa model pembelajaran ini layak untuk di ujicoba. Apabila total nilai $<15$, dan kurang dari $75 \%$, maka dapat dikatakan bahwa model pembelajaran ini belum layak untuk di ujicoba.

Berdasarkan penilaian ahli 2 Wahyu Hananingsih, M.Pd, terdapat draf awal model pembelajaran motorik dengan pendekatan bermain menggunakan permainan tradisional, terlihat bahwa dari total nilai dari masing-masing model telah memenuhi persyaratan kelayakan untuk di ujicoba di lapangan.

Tabel 9. Penilain skala nilai oleh pakar 3 (bidang ahli guru pendidikan jasmani SD)

\begin{tabular}{|c|c|c|c|c|c|c|c|c|c|c|c|c|c|c|c|c|}
\hline \multirow{2}{*}{$\begin{array}{l}\text { Model } \\
\text { permainan }\end{array}$} & \multicolumn{14}{|c|}{ Item klarifikasi } & \multirow{2}{*}{\begin{tabular}{|l|}
$\begin{array}{l}\text { Total } \\
\text { nilai }\end{array}$ \\
15 \\
\end{tabular}} & \multirow{2}{*}{$\begin{array}{l}\text { Persentase } \\
(\%) \\
100\end{array}$} \\
\hline & 1 & & & & 6 & & 8 & 9 & 10 & 11 & 12 & 13 & 14 & 15 & & \\
\hline 1 & 1 & & 1 & & 1 & 1 & 1 & 1 & 1 & 1 & 1 & 1 & 1 & 1 & 15 & 100 \\
\hline 2 & 1 & & 1 & & 1 & 1 & 1 & 1 & 1 & 1 & 1 & 1 & 1 & 1 & 15 & 100 \\
\hline 3 & 1 & . & 1 & & 1 & l & I & 1 & 1 & 1 & 1 & 1 & 1 & 1 & 15 & 100 \\
\hline 4 & 1 & . & 1. & & 1 & 1 & 1 & 1 & 1 & 1 & 1 & 1 & 1 & 1 & 15 & 100 \\
\hline 5 & 1 & 1 & 1 & & 1 & 1 & 1 & 1 & 1 & 1 & 1 & 1 & 1 & 1 & 15 & 100 \\
\hline
\end{tabular}

Keterngan: Total nilai 15, dengan persentase $100 \%$ apat dikatkan bahwa model pembelajaran ini layaka untuk di ujicoba. Apabila total nilai $<15$, dan kurang darii 75\%, maka dapat dikatakan bahwa model pembelajaran ini belum layak untuk di ujicoba.

Berdasarkan penilaian guru penjaskes Sulaeman, S.Pd, terdapat draft awal model pembelajaran motorik dengan pendekatan bermain menggunakan permainan tradisional., terlihat bahwa total nilai dari masing-masing model telah memenuhi persyaratan kelayakan untuk di ujicba di lapangan. Para pakar/ahli materi guru penjas SD telah memberikan validasi terhadap draft awal model pembelajaran motorik dengan pendekatan bermain menggunakan permainan tradisional untuk di ujicoba di lapangan.

\section{Revisi Produk Uji Coba Skala Besar}

Berdasarkan analisis data dari para ahli materi, revisi produk setelah diujicba skala besar tidak perlu dilakukan, karena para ahli menggap bahwa model pembelajaran modifikasi permainan tradisional yang terdiri dari 5 macam permainan yaitu: : (1) gobak sodor, (2) engklek/jemprak, (3) lompat kubur, (4) kucing dan tikus, dan (5) balap karung dengan pola zig- zag, yang disusun dalam bentuk buku panduan dan layak untuk digunakan.

\section{Kajian Produk Akhir}

Setelah mendapatkan penilain dan masukan, baik dari ahli materi maupun guru pendidikan jasmani sekolah dasar pelaku uji coba kemudian dilakukan proses revisi terhadap draf moodel pembelajaran yang dikembangkan. Akhirnya dihasilkan sebuah model modifikasi pemainan tradisional untk anak sekolah dasar kelas bawah, yang terdiri dari lima permainan (masing-masing meliputi beberapa bentuk modifikasi), yaitu : (1) permainan gobak sodor, (2) permainan engklek/jemprak, (3) permainan lompat kubur, (4) permainan kucing dan tikus, dan (5) permainan balap karung dengan pola zig-zag, yang disusun dalam bentuk panduan dan layak untuk digunakan.

\section{KESIMPULAN}

Sesuai dengan tujuan dari penelitian yaitu untuk dapat menghasilkan model pembelajaran dengan pendekatan permainan tradisional yang di modifikasi untuk anak sekolah dasar kelas bawah, yang layak digunakan, oleh karena itu pengamatan perkembangan dengan 7 langkah, terdiri dari (1) pengumpulan informasi di lapangan, (2) melakukan analisis terrhadap informasi yang dikumpulkan, mengembangkan produk awal (draf awal model), (4) validasi ahli dan revisi, (5) ujicoba skala kecil, dan revisi, (6) ujicoba skala besar dan revisi, (7) pembuatan prduk final.

Berdasakan hasil analisis data penilain para ahli materi, pelaku ujicoba dan kuesioner siswa terhadap model pembelajaran motorik dengan pendekatan permainan modifikasi permainan tradisional yang dikembangkan dapat disimpulkan bahwa: (1) model pembelajaran motrik dengan pendekatan bermain modifikasi permainan tradisional untuk anak sekolah dasar kelas bawah dinilai baik dan efektif, (2) respon peserta didik yang menjadi sampel dalam penelitian ini, memberikan respon yang positif terhadap model modifikasi permainan tradisional. Oleh karena itu, dapat di simpulkan bahwa melalui model pembelajaran motorik dengan modifikasi permainan tradisional dinilai dapat mengembangkan serta dapat 
meningkatkan motorik kasar anak sekolah dasar kelas bawah.

Produk penelitian dari pengembangan ini berupa model pembelajaran modifikasi permainan tradisional untuk anak sekolah dasar kelas bawah yang berisi lima permainan yaitu: (1) permainan gobak sodor, (2) permainan engklek/jemprak, (3) permainan lompat kubur, (4) permainan kucing dan tikus, dan (5) permainan balap karung dengan pola zig-zag, yang disusun dalam bentuk panduan dan layak untuk digunakan.

\section{SARAN}

Melalui model pembelajaran yang dimodifikasi dengan permainan tradisional untuk anak sekolah dasar kelas bawah, merupakan salah satu alternatif untuk digunakan Guru Penjaskes sebagai alat pembelajaran yang efektif terutama pada proses pembelajaran di lapangan, yang berupa permainan tradisional yang di modifikasi.

Dengan hasil penelitian berupa produk panduan buku pembelajaran ini, diharapkan sebagai solusi Guru Penjaskes dalam mengembangkan dan meningkatkan gerak anak sekolah dasar kelas bawah, sehingga dapat mencetak generasi yang aktif, rekreatif dan dapat membentuk kualitas generasi Bangsa yang berprestasi dan berkarakter.

\section{UCAPAN TERIMA KASIH}

Ucapan terima kasih terutama ditujukan kepada pemberi dana penelitian atau donatur yang dalam hal ini yaitu KemenristekBrin. Ucapan terima kasih juga disampaikan kepada LP2M Universitas Nahdlatul Ulama NTB yang telah memfasilitasi dan memberikan support sehingga telaksananya penelitian ini.

\section{DAFTAR PUSTAKA}

Arifin, Zainal. (2014). Evaluasi Pembelajaran: Prinsip, Teknik, Prosedur, Cet. Keenam. Bandung: PT Remaja Rosdakarya.

Decaprio, R. (2013). Aplikasi teori pembelajaran motorik di sekolah. Yogyakarta: Diva Press.

Husdarta \& Kusmaedi, Nurlan. (2010). Pertumbuhan dan perkembangan peserta didik: Olahraga dan kesehatan. Bandung: Alfabeta.

Kurdi, K., \& Sukadiyanto, S. (2014). Pengembangan Model Pembelajaran Motorik Dengan Pendekatan Bermain Menggunakan Agility Ladder Untuk Anak Sekolah Dasar. Jurnal Keolahragaan. https://doi.org/10.21831/jk.v2i2.2625

Nawawi, Handari \& Handari, Martini. (2006). Instrumen penelitian bidang sosial. Yogyakarta: Gadjah Mada University Press.

Sudijono, Anas. (2011). Pengantar statistic pendidikan. Jakarta: PT Raja Grafindo Persada.

Sukadiyanto. (2012). Prinsip pembelajaran fisik motorik pada anak usia dini. Makalah disajikan dalam pelatihan pembelajaran fisik/motorik anak usia dini, di Universitas Negeri Yogyakarta.

Sukmadinata, N.S. (2011). Metode penelitian pendidikan. Bandung: PT Remaja Rosdakarya.. 